\title{
SYSTEM IDENTIFICATION OF R/C GIRDER BRIDGES BASED ON FIELD MEASUREMENTS AND NUMERICAL SIMULATIONS
}

\author{
Damir Zenunovic, Mirsad Topalovic, Radomir Folic
}

Original scientific paper An overview of research performed in the framework of the NATO Project SfP 983828 is given in the paper. The scope of the research was to identify the parameters affecting the dynamic response of an existing $\mathrm{R} / \mathrm{C}$ girder bridge, based on ambient vibration measurements and numerical simulations using finite element models (FEM). For this purpose, the bridge across the river Bosnia near Sarajevo and the soil surrounding the bridge were instrumented. Ambient vibration tests and geophysical investigations were performed. The results are studied and a refined three-dimensional (3D) FEM is developed that takes into consideration the soil-structure interaction and superstructure-substructure interaction. The FEM's with designed parameters and parameters obtained by measurements were developed. The developed FEM models are comparatively assessed and FEM model with congruence between the measured and computationally predicted dynamic characteristics of the structure was defined. The results of the analysis show that the adequate determination of the pier, deck and bearings stiffness is the key parameter for reliable system identification.

Keywords: ambient vibration; concrete bridge; modal analysis; numerical simulation; soil investigation

Identifikacija sustava armiranobetonskih grednih mostova utemeljena na terenskim mjerenjima i numeričkim simulacijama

Izvorni znanstveni članak

U radu je dan pregled istraživanja provedenih u okviru NATO projekta SfP 983828. Predmet istraživanja je identifikacija parametara koji utječu na dinamički odziv postojećih armiranobetonskih grednih mostova, utemeljena na mjerenjima ambijentalnih vibracija i numeričkim simulacijama uporabom modela na bazi konačnih elemenata (MKE). U tu je svrhu instrumentaliziran most preko rijeke Bosne u blizini Sarajeva. Urađena su ispitivanja ambijentalnih vibracija i geofizička istraživanja. Rezultati su analizirani i urađen je poboljšani trodimenzijski numerički model koji uzima u obzir interakciju tla i konstrukcije, kao i interakciju gornjeg i donjeg stroja mosta. Razvijeni su modeli s projektnim parametrima i parametrima dobivenim mjerenjem. Urađena je komparativna ocjena razvijenih modela i verificiran model koji je imao vrijednosti dinamičkih karakteristika konstrukcije podudarne mjerenim vrijednostima. Rezultati analize pokazuju da je odgovarajuće određivanje krutosti stubova, kolovozne ploče i ležajeva ključni parameter za pouzdanu identifikaciju sustava.

Ključne riječi: ambijentalna vibracija; betonski most; istraživanje tla; modalna analiza; numerička simulacija

\section{Introduction}

Bridges are some of the most critical components of transportation infrastructure systems. For these structures, failure is defined as any interruption of pedestrian or vehicular traffic across or under them due to structural distress. Direct consequences of failure can range from injury to loss of life and property in the case of collapse, and indirect consequences such as disruptions to economic activities and reduced access to emergency facilities in the event of collapse or closure. Bridges are large and expensive structures that are of great importance to our economy and society, but they are often exposed to adverse environmental and weather conditions. Bridge engineering and monitoring can ensure their capacity to resist these conditions and thus negative impacts on our economy and society can be minimized.

According to [8] the global higher transportation network includes about 2,5 million bridges. The increasing number of bridges entails the increasing significance of maintenance problems of such engineering structures. For example, the US Federal Highway Agency (FHWA) stated in 2005 that $28 \%$ of their 595000 bridges are rated as being deficient.

Health monitoring and identification of structural modes of bridges is a major component of system maintenance. Monitoring of bridges is the recording of the actual behaviour of a complex structure, often modelled in a rather simple way thereby neglecting behaviour of the structure in three-dimensional space. Every design model is a numerical approximation of the real structure by using several assumptions which can lead to great differences between the model and the real structure. The field dynamic testing provides a direct way to obtain the real dynamic properties of bridges. Through comparison of experimental data obtained by dynamic testing and numerical data, the model can be upgraded. Finite element model updating is a numerical technique using the recorded structural response to update some selected structural parameters of the numerical model (stiffness, mass, internal forces) as well as some boundary conditions (translational or rotational springs), until an adequate agreement between numerical and experimental results is achieved. Calibration procedures for model updating provide an insight into the uncertainties related to the simplified assumptions (model topology, boundary conditions and material properties) and idealizations inevitably made during the development of FEM.

The modal characteristics of bridges can be evaluated either by identification systems that are based on ambient and earthquake-induced vibrations or by modal analysis of finite element models (FEM). Reports on testing of full-scale structures by the ambient vibration method began to appear regularly around 1970. A literature review on the subject of ambient vibration testing is presented in [11]. Recent studies, presented in references $[1,2,6,7,10,14,15]$ have shown that the results of ambient vibration tests can provide estimates of the eigen frequencies and mode shapes, as an essential parameter for the description of the vibration behaviour of a structure in the linear elastic field. Also, the structural damage identification using only measured natural 
frequencies can be successful in determining both the location and the size of damage [13].

In order to obtain the realistic structure model, a significant number of methods and the respective software have been developed for the identification of modal properties, based on ambient vibrations. Some of them were presented in references [8, 12, 13, 15]. The presented methods are used to analyse vibration signals, to obtain characteristic response and sensitivity of the parameters for the bridge. Through comparison of ambient vibration measurements and numerical data it can be concluded that the differences between the design assumptions and the actual structural properties under ambient vibrations can be accounted for the low deformation (strain) levels, the definition of the modulus of elasticity according to the code used, which is calculated at strains higher than the ones imposed by ambient vibrations, strengthening of concrete due to aging, friction mechanisms, stiffness of the bearings, as well as to construction practices during concrete casting. Also, the soil-structure interaction is deemed to be an important parameter for model updating and can significantly affect the period of vibration of the structure, as described in papers $[1,3,4,5,9]$.

Within the scope of the NATO project SfP 983828, ambient vibration tests of bridges and geophysical investigations of the soil surrounding the bridges were performed. In this paper, the results of comparative analysis of one case study are described. The experimental investigations and numerical modelling of the bridge over the river Bosna, near Sarajevo, are briefly presented. Comparative analysis of the results, with the aim of system identification of the bridge, has been performed. At the end of the paper, conclusions of the performed analysis are given.

\section{Description of the tested bridge and ambient vibration test setup}

The bridge over the river Bosnia, shown in Fig. 1a, is a 45 years old bridge located on the route M05, section Lasva-Stup. Its overall length is $117 \mathrm{~m}$ and comprises two spans of $21 \mathrm{~m}$ and three spans of $25 \mathrm{~m}$. Each span is built with four precast post-tensioned I beams of 1,30 $\mathrm{m}$ height with recessed deck, supported by 2 abutments ( 1 and 6 ) and 4 piers (2, 3, 4 and 5) through rectangular laminated elastomeric bearings. The five spans of the deck are interconnected through a $16 \mathrm{~cm}$ thick continuity slab over the piers. The bridge is instrumented for ambient vibration test. Arrangement of measuring points is shown in Fig. 1b. Ambient vibration test was made with five three-axial geophone sensors (Fig. 2). One sensor was used for the reference point (stationary point) 6R, while the remaining 4 sensors moved to individual measuring points according to the arrangement. Ambient vibration measurements were performed using Instantel Blastmate Pro4 vibration monitor with Sample Rate 1024 to 16384 $\mathrm{S} / \mathrm{s}$ per channel. The three-axial geophone sensors used had the range of measurement up to $254 \mathrm{~mm} / \mathrm{s}$, with resolution $0,127 \mathrm{~mm} / \mathrm{s}$ or $0,0159 \mathrm{~mm} / \mathrm{s}$, and accuracy $+/-$ $5 \%$ or $0,5 \mathrm{~mm} / \mathrm{s}$. Frequency Range is from 0 to $315 \mathrm{~Hz}$. The recording system has start/common trigger capabilities to enable synchronized data acquisition.

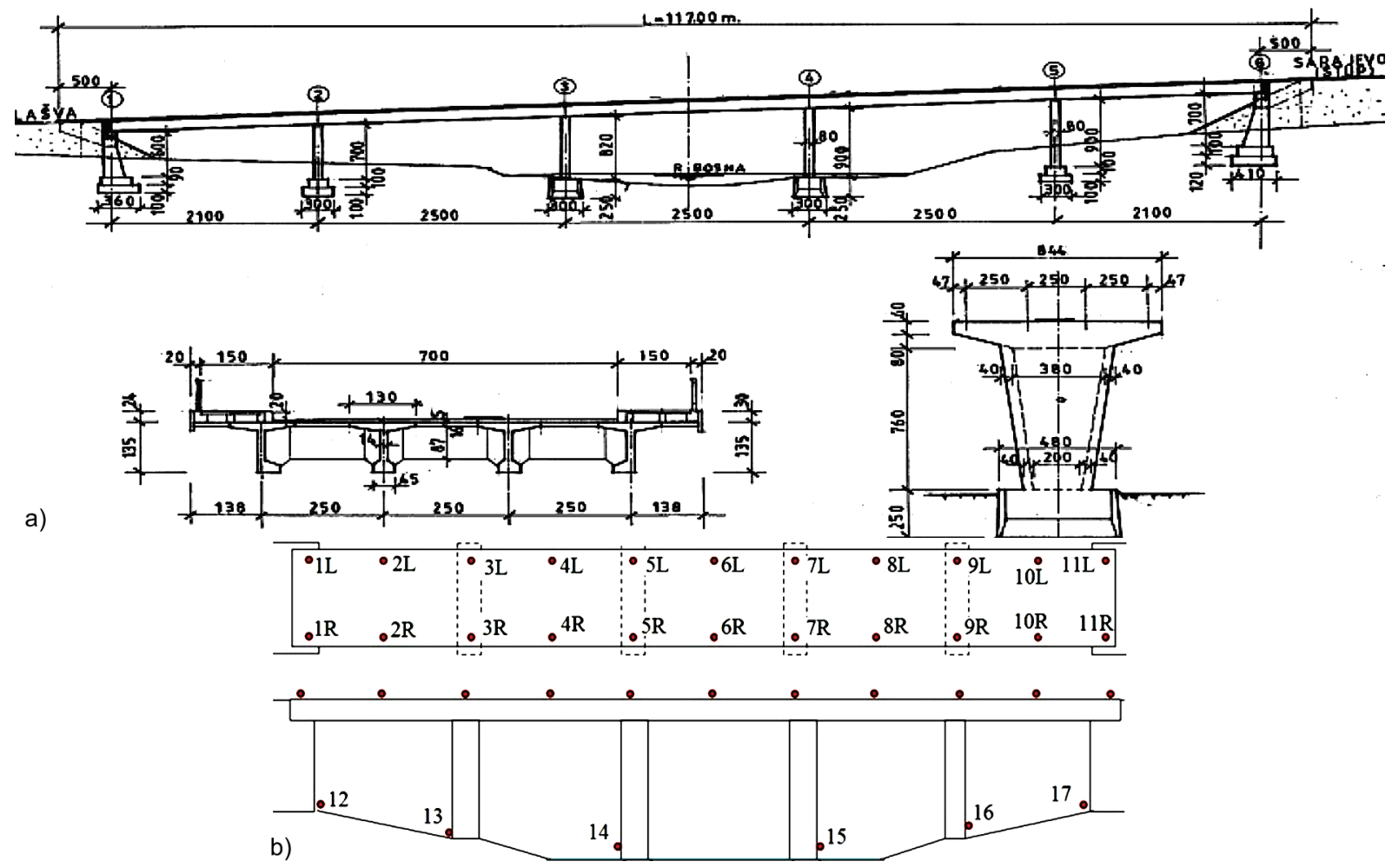

Figure 1 Bridge over river Bosnia, close to Sarajevo: (a) Cross sections; (b) Location of measuring points

\section{Ambient vibration measurements}

The sensors installed along the deck and at the bottom of the abutments and the piers recorded the bridge's response and the velocity time histories with 120 s recording time. Then, frequency spectrums were obtained by using the FFT (Fig. 3). Through this procedure the dominant frequencies were identified, and 
summarized in Tab. 1. From the results presented in the table, it can be seen that the dominant frequencies of vibration of the specific superstructure measuring points, except for a few results, are in range from 3,81 to 7,95 $\mathrm{Hz}$, depending on the position of the measuring point, over the support or in the middle of the span.

The obtained measurements (dominant frequency) were within the limits of test results on similar concrete bridges.

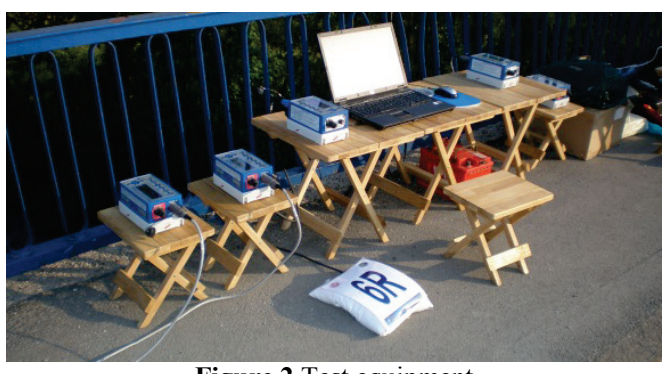

Figure 2 Test equipment
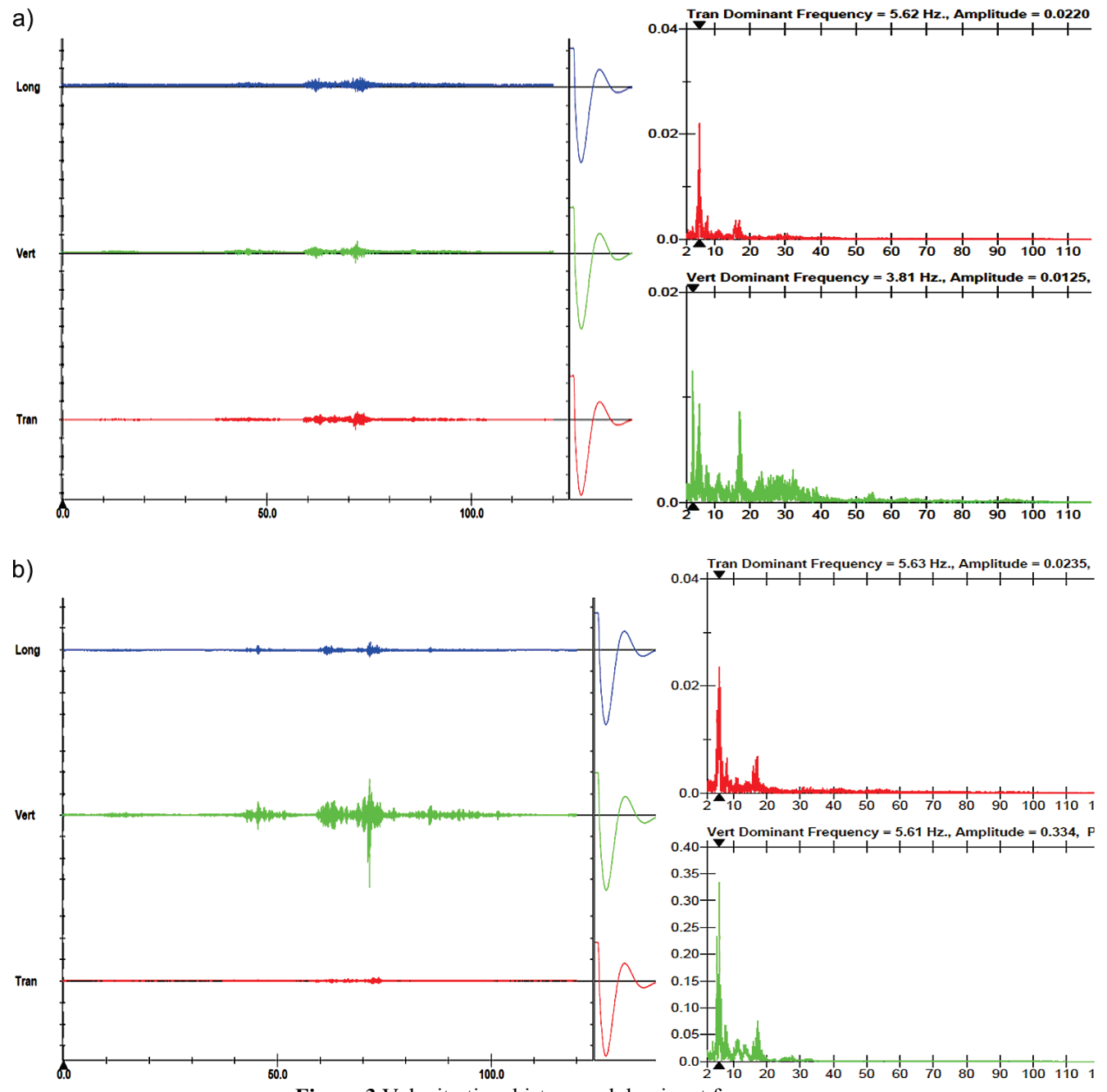

Figure 3 Velocity time history and dominant frequency:

(a) Measuring point 7R (point over support); (b) Measuring point 8R (point in the middle of span)

Table 1 Measured dominant frequency

\begin{tabular}{|c|c|c|c|c|c|c|c|}
\hline $\begin{array}{l}\text { Measuring } \\
\text { points }\end{array}$ & $\begin{array}{c}\text { Trans. Freq. } \\
(\mathrm{Hz})\end{array}$ & $\begin{array}{c}\text { Vert. Freq. } \\
(\mathrm{Hz})\end{array}$ & $\begin{array}{l}\text { Long. Freq. } \\
(\mathrm{Hz})\end{array}$ & $\begin{array}{l}\text { Measuring } \\
\text { points }\end{array}$ & $\begin{array}{c}\text { Trans. Freq. } \\
(\mathrm{Hz})\end{array}$ & $\begin{array}{c}\text { Vert. Freq. } \\
(\mathrm{Hz})\end{array}$ & $\begin{array}{l}\text { Long. Freq. } \\
(\mathrm{Hz})\end{array}$ \\
\hline $\begin{array}{c}4 \mathrm{R}, 5 \mathrm{R}, 6 \mathrm{R}, \\
7 \mathrm{R}, 8 \mathrm{R}\end{array}$ & $\begin{array}{c}5,62 ; 5,63 \\
5,47 ; 5,62 ; \\
5,63\end{array}$ & $\begin{array}{c}5,45 ; 5,60 \\
4,98 ; 3,81 \\
5,61\end{array}$ & $\begin{array}{c}5,61 ; 5,60 \\
3,81 ; 3,81 \\
3,81\end{array}$ & $\begin{array}{c}2 \mathrm{R}, 3 \mathrm{R}, 6 \mathrm{R}, \\
9 \mathrm{R}, 10 \mathrm{R}\end{array}$ & $\begin{array}{c}5,77 ; 5,97 \\
16,4 ; 5,97 ; \\
6,00\end{array}$ & $\begin{array}{c}7,69 ; 5,50 \\
4,97 ; 5,43 ; \\
7,58\end{array}$ & $\begin{array}{c}19,6 ; 5,43 ; \\
3,73 ; 5,43 ; \\
6,16\end{array}$ \\
\hline $\begin{array}{c}1 \mathrm{R}, 2 \mathrm{R}, 6 \mathrm{R}, \\
10 \mathrm{R}, 11 \mathrm{R}\end{array}$ & $\begin{array}{c}5,76 ; 5,75 \\
5,57 ; 5,75 \\
5,75\end{array}$ & $\begin{array}{c}7,85 ; 7,86 \\
4,95 ; 5,73 ; \\
5,73\end{array}$ & $\begin{array}{c}21,7 ; 5,56 \\
3,85 ; 5,56 \\
5,56\end{array}$ & $\begin{array}{c}6 \mathrm{R}, 4 \mathrm{~L}, 5 \mathrm{~L}, 6 \mathrm{~L}, \\
7 \mathrm{~L}\end{array}$ & $\begin{array}{c}5,76 ; 5,76 \\
5,76 ; 5,49 \\
5,76\end{array}$ & $\begin{array}{c}5,38 ; 5,74 \\
5,76 ; 5,36 \\
17,2\end{array}$ & $\begin{array}{c}5,48 ; 5,48 \\
5,48 ; 5,48 \\
3,88\end{array}$ \\
\hline $\begin{array}{c}6 \mathrm{R}, 3 \mathrm{~L}, 4 \mathrm{~L}, 8 \mathrm{~L}, \\
9 \mathrm{~L}\end{array}$ & $\begin{array}{c}5,54 ; 6,48 \\
5,75 ; 7,74 ; \\
5,02\end{array}$ & $\begin{array}{c}5,02 ; 5,54 \\
5,78 ; 5,02 ; \\
5,54\end{array}$ & $\begin{array}{c}3,86 ; 5,54 \\
5,54 ; 17,2 ; \\
5,54\end{array}$ & $\begin{array}{c}6 \mathrm{R}, 1 \mathrm{~L}, 2 \mathrm{~L}, \\
10 \mathrm{~L}, 11 \mathrm{~L}\end{array}$ & $\begin{array}{c}16,3 ; 6,70 \\
19,3 ; 5,67 \\
8,24\end{array}$ & $\begin{array}{c}6,85 ; 20,3 ; \\
6,70 ; 8,17 \\
20,9\end{array}$ & $\begin{array}{c}3,92 ; 7,95 ; \\
19,50 ; 6,29 \\
6,29\end{array}$ \\
\hline $\begin{array}{c}6 \mathrm{R}, 12,13,16 \\
17\end{array}$ & $\begin{array}{c}4,95 ; 14,1 ; \\
4,99 ; 2,01 ; \\
2,00\end{array}$ & $\begin{array}{c}4,99 ; 2,27 ; \\
4,99 ; 2,00 ; \\
2,01\end{array}$ & $\begin{array}{c}16,1 ; 5,50 \\
5,50 ; 2,01 \\
2,02\end{array}$ & $\begin{array}{c}6 \mathrm{R}, 12,13,16 \\
17\end{array}$ & $\begin{array}{c}6,84 ; 16,6 \\
5,84 ; 2,00 \\
2,00\end{array}$ & $\begin{array}{c}6,84 ; 2,39 \\
17,1 ; 2,00 \\
2,00\end{array}$ & $\begin{array}{c}3,91 ; 6,28 \\
6,37 ; 2,00 \\
2,00\end{array}$ \\
\hline
\end{tabular}




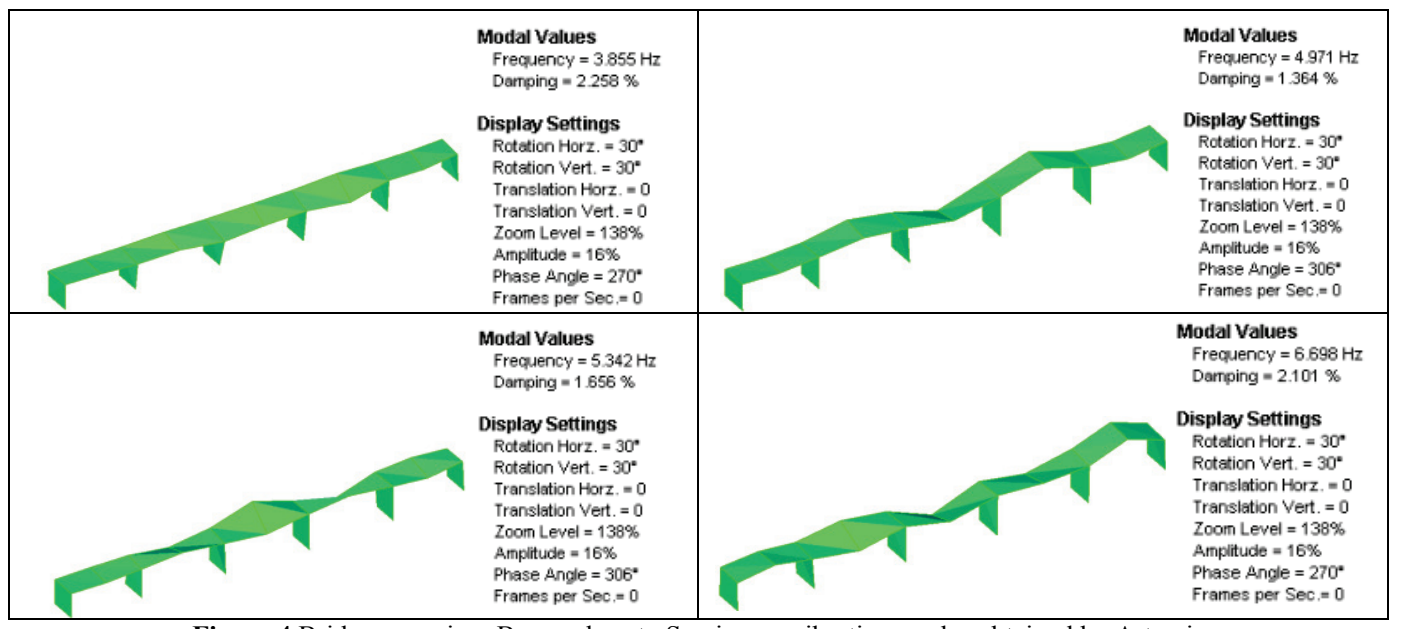

Figure 4 Bridge over river Bosna close to Sarajevo - vibration modes obtained by Artemis

The methodology of identifying structural modes via ambient vibrations is based on Enhanced Frequency Domain Decomposition (EFDD) technique, which is applied in commercial computer programs ARTEMIS. The technique is based on the decomposition of system response in a set of independent systems with one degree of freedom. Modes obtained from measurements are $3,855 \mathrm{~Hz}, 4,971 \mathrm{~Hz}, 5,342 \mathrm{~Hz}$ and 6,698 Hz (Fig. 4).

\section{Soil parameters measurements}

In the framework of the field measurements a preliminary geophysics investigation of the soil surrounding the bridge was performed. Also, the measurements of the soil ambient vibration and seismic refraction were done. Network of measuring points was established on both ends of the bridge (Fig. 5).

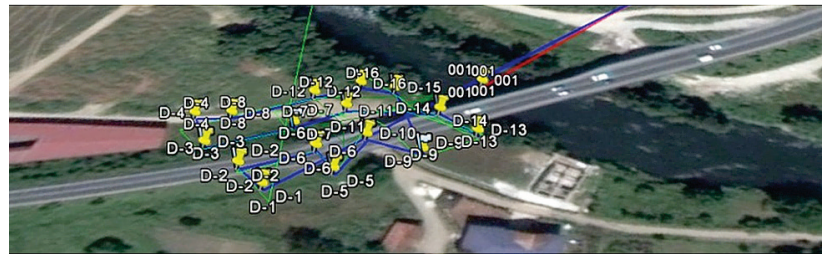

Figure 5 The network of the measurement points on the right bank

The measurements were done with the same test equipment Instantel and sensors as well as measurement of ambient vibrations of the bridge.

In Tab. 2 is given an overview of the dominant frequency of vibration of the soil on the right bank of the bridge, and in Tab. 3 review of the dominant frequency of vibration of the piers, the abutments and the soil around the abutments and piers.

Table 2 Dominant frequencies of soil vibrations on the right bank

\begin{tabular}{|c|c|c|c|c|}
\hline Measurement & Measuring point & Transv. & Vert. & Long. \\
\hline \multirow{5}{*}{$13: 24: 26$} & $6 \mathrm{R}$ & 6,63 & 5,05 & 3,79 \\
\cline { 2 - 5 } & $1^{* *}$ & 11,6 & 2,00 & 11,7 \\
\cline { 2 - 5 } & $2^{*}$ & 7,47 & 12,4 & 15,4 \\
\cline { 2 - 5 } & $3^{*}$ & 15,4 & 12,2 & 9,07 \\
\hline & $4^{* *}$ & 10,1 & 2,39 & 9,62 \\
\cline { 2 - 5 } & $6 \mathrm{R}$ & 5,45 & 5,00 & 3,97 \\
\cline { 2 - 5 } & $5^{* *}$ & 11,8 & 2,00 & 2,02 \\
\cline { 2 - 5 } & $6^{*}$ & 11,8 & 12,1 & 5,67 \\
\cline { 2 - 5 } & $7^{*}$ & 7,8 & 12,4 & 5,67 \\
\hline \multirow{5}{*}{$13: 33: 05$} & $8^{* *}$ & 15,2 & 2,13 & 13,4 \\
\cline { 2 - 5 } & $6 \mathrm{R}$ & 5,53 & 5,46 & 3,89 \\
\cline { 2 - 5 } & $9^{* *}$ & 2,13 & 2,00 & 2,00 \\
\cline { 2 - 5 } & $10^{*}$ & 16,8 & 21,4 & 13,00 \\
\cline { 2 - 5 } & $11^{*}$ & 11,9 & 21,4 & 2,78 \\
\hline & $12^{* *}$ & 2,26 & 2,01 & 2,41 \\
\hline \multirow{5}{*}{$13: 51: 56$} & $6 \mathrm{R}$ & 5,05 & 5,05 & 3,87 \\
\cline { 2 - 5 } & $13^{* *}$ & 2,26 & 2,13 & 2,26 \\
\cline { 2 - 5 } & $14^{*}$ & 16,5 & 27,7 & 17,3 \\
\cline { 2 - 5 } & $15^{*}$ & 21,3 & 16,4 & 7,94 \\
\hline
\end{tabular}

It is visible from Tab. 2 that the two sets of data related to local measurement conditions. Namely, in the areas under the bridge, arranged for the passage of the vehicle for embankment maintenance, frequency of vertical vibrations is in the range of $12 \div 22 \mathrm{~Hz}$. In the areas of natural soil vertical vibrations frequencies are 2
$\mathrm{Hz}$, similar as the abutments vertical dominant frequencies (Fig. 6). Based on the measured values of vibration of the soil around the abutments and of the abutment vibration a question may be posed: what is the share of the soil vibrations in the vibration of the structure during measuring the ambient vibration of the structure? 
The presented results of the measurements indicate that the vertical vibration of the abutments is in fact the soil vertical vibration. The difference in horizontal vibration of the soil and the abutment is understandable because in the horizontal direction the connection of the soil and the abutment is not as close as in vertical direction.

Table 3 Dominant frequencies of pier and abutment vibrations and soil vibrations close to them
\begin{tabular}{|c|c|c|c|}
\hline Measuring point & Transv. & Vert. & Long. \\
\hline \multirow{2}{*}{ ABUTMENT } & 16,6 & 2,39 & 6,28 \\
& 14,1 & 2,27 & 5,50 \\
\hline \multirow{2}{*}{ PIER } & 4,99 & 4,99 & 5,50 \\
& 5,84 & 17,1 & 6,37 \\
\hline $10^{*}$ & 16,8 & 21,4 & 13,00 \\
\hline $11^{*}$ & 11,9 & 21,4 & 2,78 \\
\hline $14^{*}$ & 16,5 & 27,7 & 17,3 \\
\hline $15^{* *}$ & 21,3 & 16,4 & 12,3 \\
\hline $9^{* * *}$ & 2,13 & 2,00 & 2,00 \\
\hline $12^{* *}$ & 2,26 & 2,01 & 2,41 \\
\hline
\end{tabular}

By comparing the soil vibration with the modes of vibration of the bridge it can be seen that during earthquake impact there is a significant effect of soilstructure in the vibration of the bridge. Also, from the measurements the important role of preparation and landscaping of the foundation soil on vertical vibrations modes can be seen. If the vertical vibration frequency range of 2 to $22 \mathrm{~Hz}$ is taken into account, depending on the arrangement of the site of measurement, it can be seen that it has an impact on the decrease or increase of the effect of soil-structure interaction.

Results of the seismic refraction are presented in Figure 6 and Tab. 4. Based on the results of seismic refraction and according to EC8, the soil is classified in category $\mathrm{C}$. The bridge is located in the seismic zone VII $\operatorname{MCS}\left(a_{g}=0,15 \mathrm{~g}\right)$.

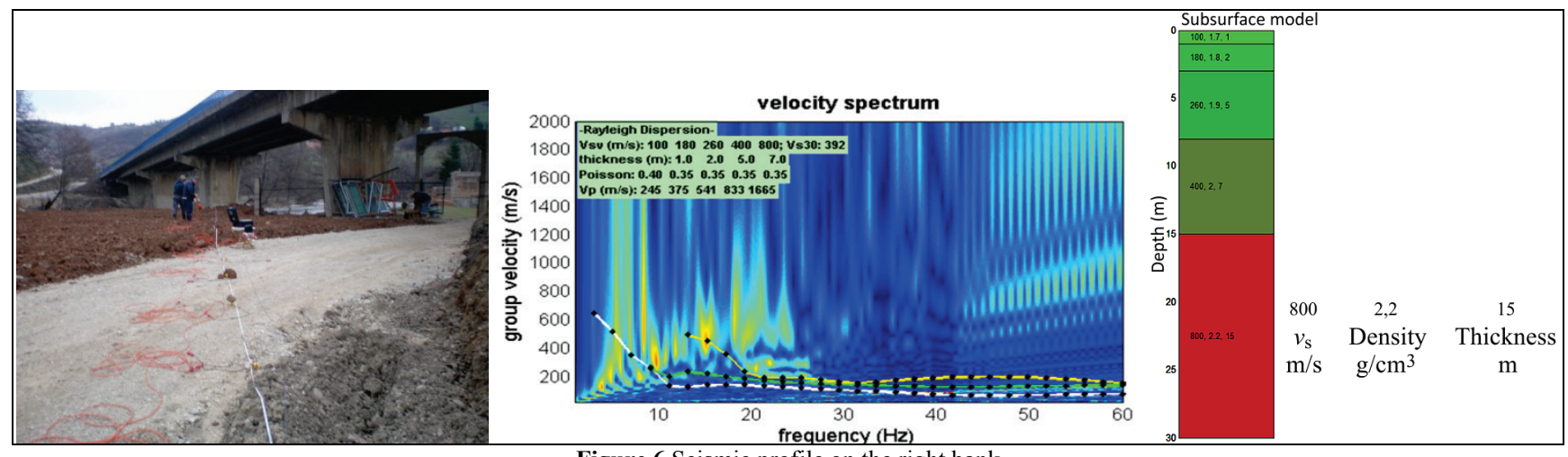

Figure 6 Seismic profile on the right bank

Table 4 Seismic refraction results

\begin{tabular}{|c|c|c|c|c|c|}
\hline \multicolumn{2}{|c|}{ Right coast } & \multicolumn{3}{c|}{ Left coast } \\
\hline Depth $(\mathrm{mm})$ & $\mathrm{S}-$ waves $(\mathrm{m} / \mathrm{s})$ & $\mathrm{P}-$ waves $(\mathrm{m} / \mathrm{s})$ & Depth $(\mathrm{mm})$ & $\mathrm{S}-$ waves $(\mathrm{m} / \mathrm{s})$ & $\mathrm{P}-$ waves $(\mathrm{m} / \mathrm{s})$ \\
\hline $0 \div 1,0$ & 100 & 245 & $0-1,0$ & 182 & 381 \\
\hline $1,0 \div 2,0$ & 180 & 375 & $1,0-2,0$ & 264 & 537 \\
\hline $2,0 \div 5,0$ & 260 & 541 & $2,0-5,0$ & 374 & 804 \\
\hline $5,0 \div 7,0$ & 400 & 833 & $5,0-7,0$ & 480 & 993 \\
\hline $7,0 \div 15,0$ & 800 & 1665 & $7,0-15,0$ & 1539 & 3208 \\
\hline \multicolumn{7}{|l|}{$v_{\mathrm{s}, 30}=392 \mathrm{~m} / \mathrm{s}$} & \multicolumn{3}{c|}{$v_{\mathrm{s}, 30}=334 \mathrm{~m} / \mathrm{s}$} \\
\hline
\end{tabular}

\section{$5 \quad$ Finite Element Models (FEMs)}

The FEMs were created using SAP2000N, based on the geometrical and material properties that were used for design, prediction of material properties after 45 years' service life and on the preliminary soil investigation. The first set of models (hereinafter called "S(1-6)-NB1-M1") is FEMs with different soil stiffness, designed neoprene bearings stiffness and designed strength of concrete, the second ("S(1-6)-NB1-M2") is FEMs with designed neoprene bearings stiffness and theoretically predicted strengthening of concrete during service life, and the third and the fourth ("S(1-6)-NB2-M2" and "S(1-6)-NB3-M2") are FEMs with increased neoprene bearings stiffness and theoretically predicted strengthening of concrete during service life.

The deck was modelled as a shell element and girders as elastic beam elements, as this approach provides effective stiffness and mass distribution characteristics of the bridge. The bridge superstructure itself is expected to remain essentially elastic during earthquake ground motions.

Dimensions of neoprene bearings are 300/400/100 $\mathrm{mm}$. Neoprene bearings are modelled with vertical and horizontal springs. The stiffness of the vertical springs was calculated using Eq. (1): 
$k=\frac{E A}{h}$,

where $E$ is the Young's modulus ( $E=630 \mathrm{~N} / \mathrm{mm}^{2}$ [16]), A is the cross sectional area, and $\mathrm{h}$ is the bearing height. The lateral shear capacity of bearings is controlled by the dynamic coefficient of friction between concrete and neoprene of 0,40 , according to [17].

Soil was modelled in two ways:

1. Soil model with linear springs, used for the structuresoil interaction (S1-S4). Spring stiffness $k=15000$ $\mathrm{kN} / \mathrm{m}^{2}$ has been selected based on experiences with similar class-C soils.

2. Layered soil model with solid elements (S5 and S6). Modulus $E$, determined by preliminary geophysics soil measurements (PGSM), was used for the solid elements. Values are calculated using software winMASW (see Tab. 5).

Table 5 Modulus $E$ for layered soil mode

Table 5 Modulus $E$ for layered soil model
\begin{tabular}{|c|c|}
\hline Depth $(\mathrm{mm})$ & $E(\mathrm{MPa})$ \\
\hline 4,0 & 1797 \\
\hline 6,0 & 3193 \\
\hline 8,0 & 7179 \\
\hline 10,0 & $\infty$ \\
\hline
\end{tabular}

The foundation structure was also modelled using solid elements so that the soil-foundation contact has been realized by identically arranged nodes of the solid soil elements and the foundation structure.

Review of the models is presented in Tab. 6. The FEMs are shown in Fig. 7.

Table 6 Review of the FEMs

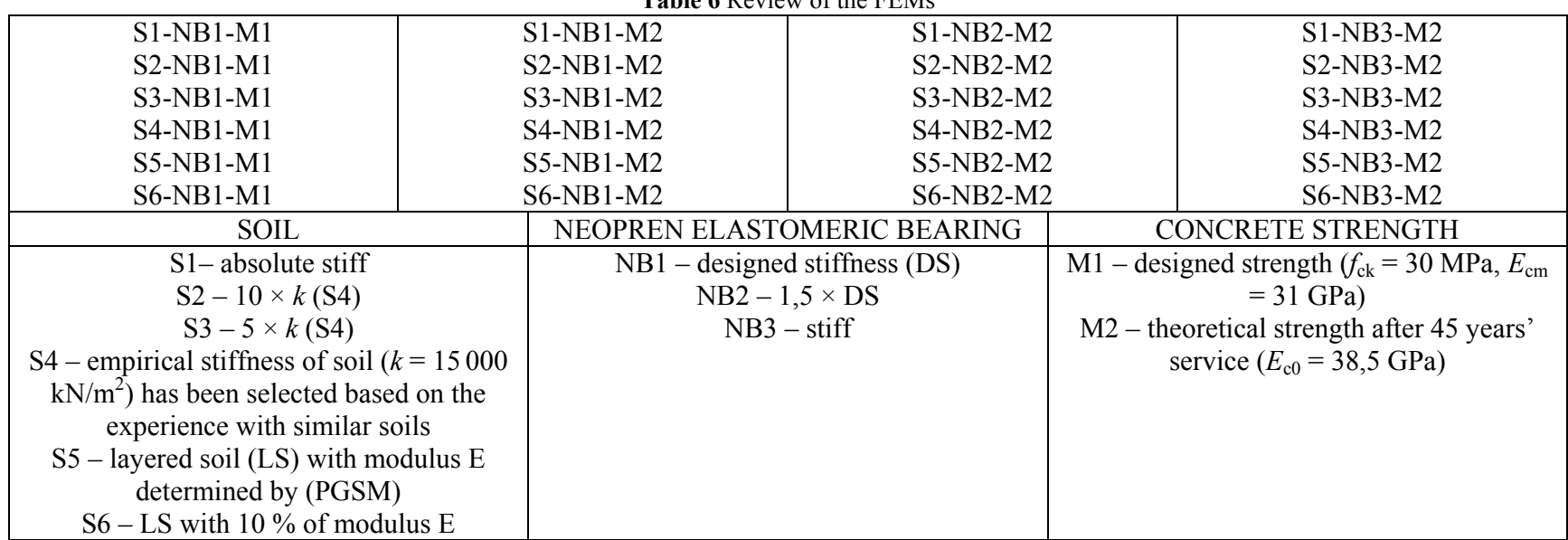

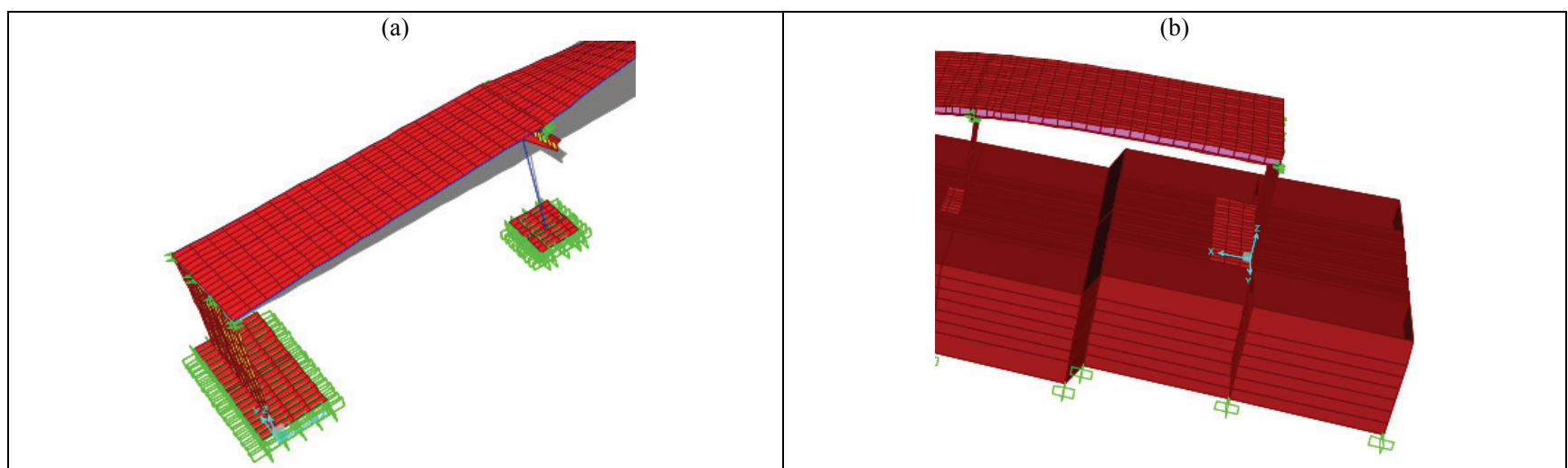

Figure 7 FEMs: (a) S1-S4; (b) S5 and S6

\section{Assessment of the predicted and measured response}

Since the scope of the research was to validate the modelling assumptions made and to identify their relative impact on the numerically predicted structural response, the developed FEMs were assessed comparatively. Through this procedure, longitudinal, transverse, bending and torsional modes were identified, whose modal frequencies are summarized in Tab. 7.

The first comparison was made between modal frequencies of the model S2-NB1-M1 and ambient vibration modal frequencies. From the presented results, it is evident that S2-NB1-M1 model fails to predict well the measured responses as they exhibit large deviations from the identified modal frequencies that exceed $57 \%$ in the transverse direction, $36 \%$ for the bending mode and $40 \%$ for the torsional mode. In general, it is observed that the modes measured via ambient vibrations are on average 44 $\%$ higher than those predicted by the model S2-NB1M1.The real structure is identified as significantly stiffer than predicted using the S2-NB1-M1model.

A second comparison was made between the models with different soil stiffness (S1-S6) in order to quantify the importance of soil compliance on the predicted dynamic characteristics of the structure. The refined consideration of soil flexibility leads to significant lower values of longitudinal, transversal and torsional modal frequencies while the reduction of bending modal frequencies is not significant. Through comparison of the 
S2-NB1-M1 model and the S3-NB1-M1 model, the longitudinal mode is found $8 \%$ more flexible, the transverse mode $14 \%$ more flexible and the torsional mode $5 \%$. The reduction of bending modal frequencies is not significant.

Since the FEMs used were refined as much as possible, the model induced uncertainty can be deemed as relatively low. As a result, the deviations between the identified and numerically predicted modal frequencies can be attributed primarily to the uncertainty in the material properties, which seem to be a key parameter for the reliable estimate of the dynamic characteristics of the structure. In order to improve the convergence, sequential parametric analysis was conducted. The idea was to gradually modify specific structural parameters through a step-by-step parametric analysis scheme, until a nearly optimal fit was achieved. The results of this parametric analysis resulted in the combination of updated structural parameters, with different neoprene bearings stiffness and concrete strength of structure elements, summarized in Tab. 7.

Table 7 Modal frequencies

\begin{tabular}{|c|c|c|c|c|}
\hline & Longitudinal mode & Transverse mode & Bending mode & Torsional mode \\
\hline $\begin{array}{c}\text { Ambient vibration } \\
\text { measurements }\end{array}$ & - & 3,855 & 4,971 & 5,342 \\
\hline \multicolumn{5}{|l|}{ FEMs } \\
\hline S1-NB1-M1 & $2,654(2)$ & $2,803(3)$ & $3,673(4)$ & $3,896(6)$ \\
\hline S2-NB1-M1 & $2,442(1)$ & $2,454(2)$ & $3,654(3)$ & $3,810(6)$ \\
\hline S3-NB1-M1 & $2,267(2)$ & $2,148(1)$ & $3,651(4)$ & $3,616(3)$ \\
\hline S4-NB1-M1 & $1,567(2)$ & $1,444(1)$ & $3,630(4)$ & $2,967(3)$ \\
\hline S5-NB1-M1 & $2,523(2)$ & $2,312(1)$ & $3,907(6)$ & $3,711(5)$ \\
\hline S6-NB1-M1 & $2,459(2)$ & $1,969(1)$ & $3,884(6)$ & $3,405(4)$ \\
\hline S1-NB1-M2 & $2,751(1)$ & $3,641(2)$ & $3,798(5)$ & $4,377(6)$ \\
\hline S2-NB1-M2 & $2,512(1)$ & $2,522(2)$ & $3,828(3)$ & $3,949(6)$ \\
\hline S3-NB1-M2 & $2,323(2)$ & $2,198(1)$ & $3,824(4)$ & $3,737(3)$ \\
\hline S4-NB1-M2 & $1,586(2)$ & $1,448(1)$ & $3,794(6)$ & $3,030(3)$ \\
\hline S5-NB1-M2 & $2,614(2)$ & $2,369(1)$ & $4,081(6)$ & $3,806(5)$ \\
\hline S6-NB1-M2 & $2,542(2)$ & $2,011(1)$ & $4,054(6)$ & $3,483(3)$ \\
\hline "S1-NB2-M2 & $2,971(1)$ & ב3,731 (2) & $3,825(3)$ & 44,443(6) \\
\hline S2-NB2-M2 & $2,666(2)$ & $2,556(1)$ & $3,860(3)$ & $4,065(6)$ \\
\hline S3-NB2-M2 & $2,442(2)$ & $2,224(1)$ & $3,857(3)$ & $3,857(4)$ \\
\hline S4-NB2-M2 & $1,627(2)$ & $1,467(1)$ & $3,827(6)$ & $3,124(3)$ \\
\hline S5-NB2-M2 & $2,804(2)$ & $2,411(1)$ & $4,184(6)$ & $4,126(5)$ \\
\hline S6-NB2-M2 & $2,715(2)$ & $2,046(1)$ & $4,156(6)$ & $3,755(4)$ \\
\hline S1-NB3-M2 & $3,574(1)$ & 4,246 (3) (Fig. 8a) & $4,136(2)$ & 5,026 (5) (Fig. 8b) \\
\hline S2-NB3-M2 & $3,207(2)$ & $2,689(1)$ & $4,261(3)$ & $4,383(4)$ \\
\hline S3-NB3-M2 & $2,915(2)$ & $2,317(1)$ & $4,253(4)$ & $4,143(3)$ \\
\hline S4-NB3-M2 & $1,965(2)$ & $1,528(1)$ & $4,198(4)$ & $3,320(3)$ \\
\hline S5-NB3-M2 & $3,407(2)$ & $2,513(1)$ & 4,639 (3) (Fig. 8c) & $4,847(3)$ \\
\hline S6-NB3-M2 & $3,239(2)$ & $2,146(1)$ & $4,609(4)$ & $4,318(3)$ \\
\hline
\end{tabular}

(n) marks in parenthesis denote modes of certain models
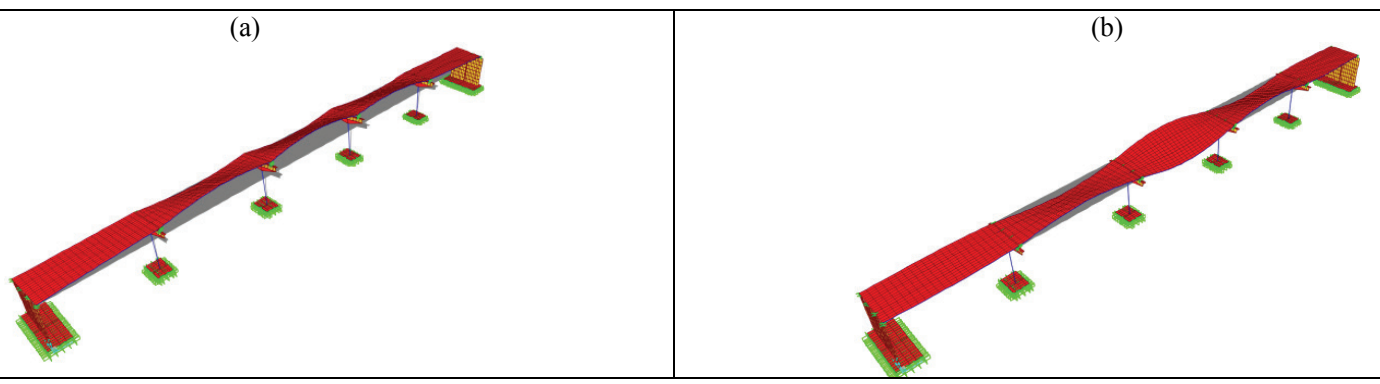

(c)

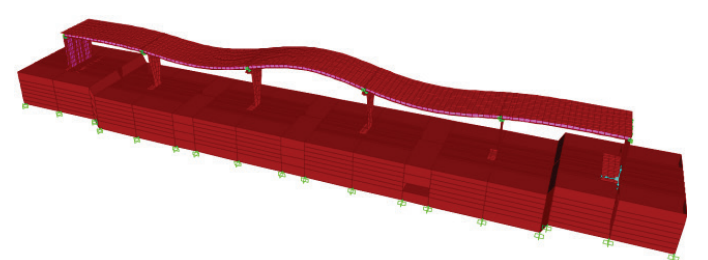

Figure 8 Numerically predicted modes:

(a) Transverse mode of S1-NB3-M2 model; (b) Torsional mode of S1-NB3-M2 model; (c) Bending mode of S5-NB3-M2 model

The results presented in Tab. 7 show the improvement of the modal frequencies predicted by the models S1-NB2-M2, S1-NB3-M2 and S5-NB3-M2 compared to the modal frequencies predicted by the $\mathrm{S} 2-$ 
NB1-M1 model. By comparing the modal frequencies predicted by the mentioned models it is clear that the Young Modulus of Elasticity for the bearings, the deck and the piers had to be significantly increased compared to the values assumed in the initial design. This can be clearly attributed to the low deformation (strain) levels that are developed under ambient vibrations at which the bearing stiffness is significantly higher than that assumed during design. Also, the effect of concrete strengthening during service life has to be considered.

\section{Conclusions}

The goal of the paper was to identify the parameters that affect the dynamic response of the instrumented bridge over river Bosna.

Using FEMs with various levels of complexity and modelling refinement in terms of consideration of the soil parameters and structure material parameters, the modal frequencies of the bridge are computed and compared with the ones identified using ambient vibrations.

From the presented results of the analysis it can be concluded:

(a) In ambient vibration test of the bridge structure the question, what share of soil vibrations is in the bridge structure vibration, remains open.

(b) The differences between the design assumptions and the actual structural properties under ambient vibrations can be attributed to the low deformation (strain) levels, the definition of the modulus of elasticity according to the code used, which is calculated at strains higher than the ones imposed by ambient vibrations, strengthening of concrete due to aging, friction mechanisms as well as to construction practices during concrete casting.

(c) Ambient vibration test of the bridge cannot be efficiently used to define the soil-structure interaction nor the interaction between superstructure and substructure in discontinuous bridges and bridges with neoprene bearings. The reason for this is that at very low excitation intensity, such as ambient effects, these effects cannot be activated. It can be concluded that for the modelling of bridge structures, with the application of the link elements for bearings connections, it is necessary to apply the forced vibration test, or a combination of the forced vibration test and ambient vibration test. Ambient vibration test has proven to be successful in frame and integral bridges.

(d) Consideration and numerical modelling of soilstructure interaction may not affect the dynamic characteristics drastically in terms of their absolute values, but due to significant modal coupling, it had a considerable effect on the prediction of the final, modified structural parameters. This effect is anticipated to be further pronounced in case of softer soil profiles. As a result, the accurate soil-structure interaction modelling is deemed to be a key parameter for reliable modal updating of extended bridge-soil systems.

(e) Modelling of soil-structure interaction significantly affects the longitudinal and transverse vibration modes. Therefore it can be concluded that the transverse and longitudinal vibration modes of the discontinuous bridges (bridges that are not an integral or a frame) cannot be determined sufficiently reliably using ambient vibrations tests.

\section{Acknowledgement}

This paper is a part of the research that is performed within the NATO SfP 983828 scientific project "Seismic Upgrading of Bridges in South East Europe by Innovative Technologies".

\section{References}

[1] Sextos, A.; Faraonis, P.; Papadimitriou, C.; Panetsos, P. System identification of a $\mathrm{R} / \mathrm{C}$ bridge based on ambient vibration and $3 \mathrm{D}$ numerical simulations of the entire soilstructures system. // COMPDYN 2011, Proceeding of the $3^{\text {rd }}$ ECCOMAS Thematic Conference on Computational Methods in Structural Dynamics and Earthquake Engineering / Corfu, Greece, 25-28 May 2011, pp. 1-16.

[2] Ventura, C. E.; Finn, W. D. L.; Wagner, P. R.; Felber, A. J. Ambient Vibration Studies of three Short-Span Reinforced Concrete Bridges. // Proceeding of the Eleventh World Conference on Earthquake Engineering / Acapulco, Mexico, 23-28 June 1996, Paper No. 921.

[3] Jeremic, B.; Kunnath, S.; Larson, L. Soil-FoundationStructure Interaction Effects in Seismic Behavior of Bridges. // Proceeding of the $13^{\text {th }}$ World Conference on Earthquake Engineering / Vancouver, Canada, August 0106 2004, Paper No. 294.

[4] De Carlo, G.; Dolce, M.; Liberatore, D. Influence of SoilStructure Interaction on the Seismic Response of Bridge Piers. // Proceeding of the $12^{\text {th }}$ World Conference on Earthquake Engineering / Auckland, New Zealand, January 30-February 04, 2000, Paper No. 0438.

[5] Mylonakis, G.; Gazetas, G. Seismic Soil-Structure Interaction: Beneficial or Detrimental? // Journal of Earthquake Engineering. 4, 3(2000), pp. 277-301. DOI: 10.1080/13632460009350372

[6] Gentile, C.; Saisi, A. Bridge modal identification form short length ambient vibration responses // Proceeding of the $26^{\text {th }}$ Conference on Our World in Concrete \& Structures / Singapore, August 27-28, 2001, pp. 239-246.

[7] Wenzel, H.; Pichler, D. Ambient Vibration Monitoring. A John Wiley and Sons Ltd Publication, United Kingdom, 2005.

[8] Wenzel, H. Health Monitoring of Bridges. A John Wiley and Sons Ltd Publication, United Kingdom, 2009.

[9] Saadeghvaziri, M. A.; Yazdani-Motlagh, A. R.; Rashidi, S. Effects of soil-structure interaction on longitudinal seismic response of MSSS bridges. // Soil Dynamics and Earthquake Engineering. 20(2000), pp. 231-242. DOI: 10.1016/S0267-7261(00)00056-7

[10] Soyoz, S.; Feng, M.Q. Long-Term Monitoring and Identification of Bridge Structural Parameters. // ComputerAided Civil and Infrastructure Engineering. 24(2009), pp. $82-92$.

[11] Ivanovic, S. S.; Trifunac, M. D.; Todorovska, M. I. Ambient Vibration Tests of Structures - A Review. // ISET Journal of Earthquake Technology. 37, 4(2000), pp. 165197.

[12] Liu, T. Y.; Chiang, W. L.; Chen, C. W.; Hsu, W. K.; Lu, L. C.; Chu, T. J. Identification and monitoring of bridge health from ambient vibration data. // Journal of Vibration and Control. 17(4), pp. 589-603. DOI: 10.1177/1077546309360049 
[13] Mekjavic, I. Damage Identification of Bridges from Vibration Frequencies. // Tehnički vjesnik-Technical Gazette, 20, 1(2013), pp. 155-160.

[14] Haghighi, A. A. M. K. Vibration-based Damage Detection and Health Monitoring of Bridges. A dissertation submitted to the Graduate Faculty of North Carolina State University, 2010.

[15] Ren, W.-X.; Zatar, W.; Harik, I. E. Ambient vibrationbased seismic evaluation of a continuous girder bridge. // Engineering Structures. 26, (2004), pp. 631-640. DOI: 10.1016/j.engstruct.2003.12.010

[16] Sveučilište u Zagrebu, Građevinski fakultet, Zavod za konstrukcije, Katedra za mostove. Separat 3 - Oprema mosta. http://www.grad.unizg.hr/_download/repository/ Separat_3_-_Oprema_mosta.pdf/. (25.11.2014)

[17] Caltrans, Bridge Design Specification, California Department of Transportation. http://www.dot.ca.gov/hq/ esc/techpubs/manual/bridgemanuals/bridge-designspecifications/page/section14.pdf (25.11.2014)

\section{Authors' addresses}

Prof. dr. Damir Zenunovic, Civ. Eng.

University of Tuzla, Faculty of Mining,

Geology and Civil Engineering

Univerzitetska 2, 75000 Tuzla, Bosnia and Herzegovina

E-mail: damir.zenunovic@untz.ba

Ass. Prof. Mirsad Topalovic, Civ. Eng.

University of Tuzla, Faculty of Mining,

Geology and Civil Engineering

Univerzitetska 2, 75000 Tuzla, Bosnia and Herzegovina

E-mail: mirsad.topalovic@untz.ba

Prof. dr. Radomir Folic, Civ. Eng.

University of Novi Sad, Faculty of Technical Sciences

Trg D. Obradovica 6, 21000 Novi Sad, Serbia

E-mail: r.folic@gmail.com 